\title{
Skillful Lecturers: Arabic Teaching Experiences during COVID 19 Pandemic
}

\author{
Penny Respati Yurisa ${ }^{1, *}$, Muassomah Muassomah ${ }^{2}$
}

\author{
${ }^{1}$ Department of Arabic Literature, Universitas Islam Negeri Maulana Malik Ibrahim Malang, Indonesia \\ ${ }^{2}$ Department of Arabic Literature, Universitas Islam Negeri Maulana Malik Ibrahim Malang, Indonesia \\ *Corresponding author. Email: penny@bsa.uin-malang.ac.id
}

\begin{abstract}
The shift of the learning system from offline to online is a challenge for higher education lecturers. It demands creativity and innovation in designing the learning system, teaching strategies, methods, and evaluations to measure the students' abilities and understanding. Those who are accustomed to teaching face-to-face might find it hard to switch to online. They need to learn to operate the platform. This study describes lecturers' experiences in teaching online during the Covid-19 pandemic. It is a qualitative descriptive study with a phenomenological approach. The data are obtained from interviews with lecturers at the Center for Arabic Language Development at UIN Maulana Malik Ibrahim Malang. This study shows that the challenges in teaching Arabic online raise the lecturers' creativity and innovation through various technology-based teaching activities. They even use several online applications in delivering the materials, such as Zoom, Google Meet, Google Classroom, WhatsApp, and Email. Technology-based teaching is a new transformation in education, especially in teaching Arabic.
\end{abstract}

Keywords: Skillful Lecturer, Teaching Experience, COVID-19 Pandemic

\section{INTRODUCTION}

The Arabic language learning process at UIN Maulana Malik Ibrahim Malang has been shifted from the offline to online during COVID-19 pandemic. It causes some lecturers panic and requires them to study various platforms. Not all lecturers are ready for this change, and many obstacles bother [1]. It is experienced by lecturers, teachers, and prospective teachers in schools and in carrying out online learning during the Covid 19 pandemic. The Covid 19 pandemic has made all people engaged in academics readily move to provide solutions for the offline learning process which is constrained by paying attention to the technology that developed during this industrial 4.0 era. By trying to use technology at this time will affect the success of learning [4]. The Covid 19 pandemic has caused many changes in every line of life, especially the learning process from face-to-face to online. It provides a lot of wisdom [5] [6] Tasri 2020) and even makes it stressful for some students, as happened at UIN Syarif Hidayatulloh. Distance lecturing has a relationship with smartphone disorders and stress [8].

Before the pandemic, the classroom means a room for learning. There is an interaction between lecturers and students. Now, people interpret the class as a virtual space in the network. Government policies related to home learning also experience many challenges [9]. There have been many studies related to learning during the COVID-19 pandemic, such as those written by [11] [12]. They all focus on the learning process during the COVID-19 pandemic. There are many studies related to the pandemic, but no one has examined lecturers' teaching skills during the pandemic. Most researchers discussed the impact of COVID-19 on learning and the obstacles experienced during the COVID-19 pandemic [13][14] [15]. It is also essential to discuss about skillful teachers. Therefore, a research related to teachers' skill can motivate academics who need ideas for dealing with online learning. 
The Language Development Center at UIN Maulana Malik Ibrahim Malang also implements an online learning during the COVID-19 pandemic. It is quite interesting to know the skills the lecturers should possess during the lecture system change from the offline to the online one. It might include the method of delivering the material, the media, and the evaluation model. This study argues that the online teaching of Arabic in PPBA (Arabic Language Development Program) has led to advantages and disadvantages, which need to be explored to contribute to the Arabic language lecturers in particular, and those of the other fields in general. Through interviews with the lecturers at PPBA UIN Maulana Malik Ibrahim Malang, it examines the difference between offline and online teachings.

\section{METHOD}

The current research is descriptive qualitative, whose data are derived from the interview with Arabic lecturers at PPBA UIN Maulana Malik Ibrahim Malang. They are explored under three points: the way of delivering the materials, the strategies, methods, and media used in learning, and the evaluation method in teaching Arabic. The interview is conducted via Whatsapp due to the COVID-19 pandemic. It employs a phenomenology approach, observing the phenomenon of teaching Arabic during the pandemic.

Data analysis was carried out in three qualitative research stages: data reduction, data presentation, and conclusion drawing. Data reduction is made by mapping the collected data, selecting and sorting them according to the research topic. The data are presented in three tables: the first is related to the material delivery, the second is about the strategies, methods, and media used, and the third is about evaluation. Data are presented in tables for mapping and classification. Finally, they are interpreted and described clearly until the conclusion is precisely made.

\section{RESULTS AND DISCUSSION}

\subsection{Online learning material delivery}

The Covid-19 pandemic is a precondition for a shift in the tradition of teaching Arabic in PPBA. Previously, teaching was done face to face, and now we need to do it online. The material delivery has also changed from detailed explanations and reviews and hands-on practice and experience, yet now more assignments are given. The detail is provided in table 1 .

Table 1. Online Learning Material Delivery

\begin{tabular}{|c|c|c|}
\hline NO & Lecturer Experience & Code \\
\hline 1 & $\begin{array}{l}\text { Shorter time is spent. } \\
\text { The lecturer only uses } \\
\text { it for sending and } \\
\text { collecting assignments. }\end{array}$ & Minimal time \\
\hline 2 & $\begin{array}{l}\text { More relaxed at home } \\
\text { as lecturers do not } \\
\text { need to wear formal } \\
\text { clothes, yet the } \\
\text { material delivery is not } \\
\text { maximum. }\end{array}$ & More relaxed \\
\hline 3 & Online lacks meaning. & Less meaningful \\
\hline 4 & $\begin{array}{l}\text { Sending a photo to } \\
\text { WhatsApp groups, } \\
\text { then each student write } \\
\text { a comment on the } \\
\text { photo in Arabic }\end{array}$ & $\begin{array}{l}\text { Submission with } \\
\text { the media }\end{array}$ \\
\hline 5 & $\begin{array}{l}\text { Using a booming } \\
\text { application very often, } \\
\text { such as Tiktok, vlogs } \\
\text { and video editing } \\
\text { applications. }\end{array}$ & Platform variations \\
\hline 6 & $\begin{array}{l}\text { Delivering material } \\
\text { using multiple } \\
\text { platforms }\end{array}$ & Platform variations \\
\hline 7 & $\begin{array}{l}\text { Each meeting has a } \\
\text { limited time, } \\
\text { sometimes one } \\
\text { meeting is only used } \\
\text { for material delivery } \\
\text { while the evaluation is } \\
\text { made in the following } \\
\text { week, or sometimes it } \\
\text { switches to a } \\
\text { communication } \\
\text { platform, such as } \\
\text { Whatsapp. }\end{array}$ & Minimal time \\
\hline
\end{tabular}

The material delivery of Arabic at PPBA has changed from offline at 14.00 to 17.00 to online learning. Table 2 shows seven ways used by the lecturers to deliver materials during online teaching. The online learning system for lecturers takes longer than offline ones. Learning that takes place face-to-face by lecturers tends to use a lecture model, so there is no need to prepare the material to be present. Unlike offline teaching, the online class needs more time and demands more preparation of the materials students can access 
online. However, lecturers are not ready enough to use the platform to deliver the materials. The obstacle is also the signal and internet data to access the platform. This situation causes the lecturer to deliver the materials by only sending files without any virtual explanation. Daniel states that learning has provided high flexibility, so it is necessary to improve the students' learning pathways during the pandemic and increase the teachers' digital literacy [16].

Also, online learning feels more relaxed, where the lecturers do not need to prepare with maximum performance when explaining material online. Lecturers feel that they cannot maximally deliver the materials online. They feel that online class lacks meaningfulness due to the absence of direct interaction between in the classroom. Verbal and non-verbal communication can be found only in the classroom by which warmth might be made. Lecturers are still not ready to carry out the online learning tradition, which results in less innovative learning. It also lacks lecturers' efforts to try learning that contains technological elements or is associated with new things during the pandemic. Online learning policy forces lecturers to be creative and learn how to use the online platforms for the learning process during the pandemic. As stated by Wahyono, teachers' competence and skills must be continuously developed and enriched, which cannot be separated from the contribution of local educational institutions and the government [17].

Before the pandemic, lecturers also invite students to practice their speaking directly by visiting places such as malls, museums, and other public places. Due to the outbreak, direct practice in the field is impossible to do. Lecturers are forced to look for other alternatives in delivering materials, so that the class is not boring and can raise the atmosphere, such as Tiktok, vlogs, and other interesting applications. Lecturers can deliver the materials directly, easily, and quickly because the classes are conducted face-to-face via Zoom or Google Meet platform. The inevitable online learning creates challenges for creativity in the use of various applications. The online learning's ineffectiveness cannot be solved in one face to face because some learning platforms do not provide two-way communication spaces. The online teachings at PPBA seem to be pursuing the materials' volume in completing the textbooks in one semester, without paying any attention to the students' understanding over the four language skills.

\subsection{Teaching and Online Strategies}

Changes in the learning system from the offline to online have impacted changes in a series of educational processes. They demand lecturers to adapt with the technology and creativity in teaching strategies, methods, and media, as illustrated in table 2 .

Table 2. Arabic Language Teaching Strategies, Methods, and Media

\begin{tabular}{|c|c|c|}
\hline No & Lecturer Experience & Code \\
\hline 1 & $\begin{array}{l}\text { Using various online } \\
\text { platforms, such as } \\
\text { Whatsapp, } \\
\text { Facebook, Youtube, } \\
\text { and WEB }\end{array}$ & Platform variant \\
\hline 2 & $\begin{array}{l}\text { Using Whatsapp } \\
\text { group, Whatsapp } \\
\text { voice note }\end{array}$ & Specific platform \\
\hline 3 & $\begin{array}{l}\text { Sending a text image } \\
\text { and reading aloud } \\
\text { using Whatsapp } \\
\text { voice note }\end{array}$ & Specific platform \\
\hline 4 & $\begin{array}{l}\text { Using GO LIVE } \\
\text { Facebook platform, } \\
\text { then students answer } \\
\text { using chat on } \\
\text { Facebook as well for } \\
\text { variations in the } \\
\text { learning atmosphere } \\
\text { besides Whatsapp } \\
\text { group }\end{array}$ & Effective platform \\
\hline 5 & $\begin{array}{l}\text { Using zoom, google } \\
\text { meet, classroom, and } \\
\text { Whatsapp group for } \\
\text { presentations and } \\
\text { QnA }\end{array}$ & Collaborative platform \\
\hline 6 & $\begin{array}{l}\text { Using Whatsapp } \\
\text { voice recording to } \\
\text { improve speaking } \\
\text { skills }\end{array}$ & Effective platform \\
\hline 7 & $\begin{array}{l}\text { Using video call } \\
\text { with } 4 \text { students in } \\
\text { turns to maintain } \\
\text { intimacy between } \\
\text { lecturers and } \\
\text { students. }\end{array}$ & Collaborative platform \\
\hline
\end{tabular}

The learning shift has led some lecturers to change the strategies, methods, and media commonly used in the offline classes adjusted according to the online learning needs. They also employ various online learning platforms, such as Whatsapp, Youtube, 
Facebook, Telegram, and Google. Zoom is not familiar to use at the beginning of the pandemic, but Whatsapp became the favorite platform where almost all lecturers use it for teaching. Changes in strategies, methods, and media for teaching Arabic at PPBA are inevitable. Before the pandemic, lecturers use a jigsaw, role play, and other language games, which have created collaborative and active roles for students.

Meanwhile, almost all lecturers switched to WhatsApp and Google; even some use Youtube and Facebook. WhatsApp is the favorite platform because it is more practical, and it does not spend much quota. Even WhatsApp is possible for those living in unstable signal areas.

Usually, in offline learning, the lecturer opens the book and teaches by lecture and direct discussions with the students. In contrast to online learning, the material is converted into files shared via WhatsApp. Then, the lecturer explains it using voice notes, one of the application's features. This method is second-rate, but still, WhatsApp is a practical application for teaching. Before the pandemic, the lecturers use language games to liven up the classroom atmosphere. Yet, when learning shifts into online, lecturers are used to going live, a feature on Facebook for various teaching platforms besides WhatsApp. It is different from other research stating that online learning at the college has been effective by utilizing several applications such as Zoom, Google Classroom, Schoology, and Edmodo [1].

The learning process in the large classes with 30-35 students let the lecturers think of using a platform that can replace the offline class, such as Zoom, Google Meet, Google Classroom, and WhatsApp group for the QnA media. The application can accommodate more than 100 students, making it suitable for classroom model learning with more than 30 students. Also, lecturers think about improving the students' speaking skills during the online classes. In conventional learning, lecturers use the drama method to enhance their speaking skills and confidence, yet the drama cannot be possibly made at this moment due to the physical distancing regulations. Therefore, lecturers replace it with a task of voice over as if they were having a conversation. This strategy supports improving their speaking skills because lecturers can also measure their fluency in speaking Arabic.

The education system's shift is difficult for the lecturers, especially PPBA homeroom lecturers, to build familiarity with students. Before the pandemic, every two weeks, homeroom lecturers often use drama and poetry readings as variations and efforts to build intimacy among class members. Building intimacy, drama, and poetry recitation also train students' confidence in speaking Arabic. Then, lecturers shift into video calls and chat with four members as a medium to build intimacy among class members. It is in line with the obstacles experienced by the teachers of SMPN 3 Bae Kudus. They have network instability, the teacher's voice and teaching materials nonsimultaneous, classes based on the wifi or network availability, and reduced concentration [18].

\subsection{The evaluation of the Arabic offline and online class}

Table 3. Online Teaching Evaluation

\begin{tabular}{|c|c|c|}
\hline No & Offline & Online \\
\hline 1 & $\begin{array}{l}\text { Cannot ensure if the } \\
\text { students have mastered the } \\
\text { materials because some } \\
\text { platforms do not provide } \\
\text { direct communication } \\
\text { services. }\end{array}$ & Not interactive \\
\hline 2 & $\begin{array}{l}\text { It is more tiring to have to } \\
\text { be in a file and haven't } \\
\text { found a way to correct it } \\
\text { faster because you have to } \\
\text { correct it yourself. }\end{array}$ & More tiring \\
\hline 3 & $\begin{array}{l}\text { Students who do not } \\
\text { understand the material ask } \\
\text { questions by sending } \\
\text { messages through platforms } \\
\text { and cannot be responded } \\
\text { directly because they are } \\
\text { separated from space and } \\
\text { time, except the live-stream } \\
\text { platform. }\end{array}$ & $\begin{array}{l}\text { Slow response } \\
\text { to questions }\end{array}$ \\
\hline 4 & $\begin{array}{l}\text { It is difficult to do } \\
\text { evaluation because the } \\
\text { learning process is not face } \\
\text { to face. }\end{array}$ & $\begin{array}{l}\text { Difficult to } \\
\text { evaluate and } \\
\text { provide } \\
\text { feedback }\end{array}$ \\
\hline 5 & $\begin{array}{l}\text { Students' assignments } \\
\text { cannot be assessed directly. }\end{array}$ & $\begin{array}{l}\text { Difficult in } \\
\text { giving } \\
\text { assessment }\end{array}$ \\
\hline 6 & $\begin{array}{l}\text { Lecturers cannot measure } \\
\text { the students' learning } \\
\text { motivation. }\end{array}$ & $\begin{array}{l}\text { Learning } \\
\text { cannot see } \\
\text { changes } \\
\text { directly }\end{array}$ \\
\hline 7 & $\begin{array}{l}\text { Feedback in the learning } \\
\text { process cannot be conveyed } \\
\text { directly. }\end{array}$ & $\begin{array}{l}\text { Unable to } \\
\text { respond } \\
\text { immediately }\end{array}$ \\
\hline
\end{tabular}


A series of teaching and learning processes cannot be separated from evaluation, which aims to determine whether the learning process is going well or not. It is more important than knowing whether the lecturers have achieved the teaching objectives. The evaluation of the Arabic language teaching process at PPBA has been shifted also into virtual. Lecturers have made many teaching evaluation innovations to determine the teaching achievement, as provided in table 3 .

Table 3 explains that the evaluation process by PPBA lecturers also experience a shift. When the learning is carried out offline, the lecturer can determine how deep the students understand the materials by looking at their facial expressions. In contrast, the lecturer cannot confirm students' understanding of the materials presented online. The reason is that some of the platforms used by lecturers at the beginning of the pandemic do not provide interactive communication services, such as Google Classrooms, Email, and YouTube. Regarding the assessment, the students' work can be evaluated together with the other students in the offline class. There is a direct reciprocal interaction related to the errors and the way to avoid them. Lecturers feel that peer reviews make the assessment very easy because it can save energy and time.

Meanwhile, the evaluation during online learning is tiring because the lecturers have to evaluate by themselves. The students' work in the form of a file on the monitor causes the eyes tired. Lecturers need a lot of time to assess, not to mention the many household activities, especially for the female lecturers, which breaks their concentration. The learning evaluation conducted by the lecturers offline is considered very easy. Giving feedback to students can also be done directly. Students can also now confirm the feedback that they do not understand.

Meanwhile, it is challenging to give free feedback during online teaching because usually, in offline learning, the lecturer can provide feedback freely in a written or short verbal explanation. The online class makes it difficult to do. The feedback is usually conveyed in writing, while the confirmation is performed via WhatsApp. The WhatsApp platform is not limited in time. Sometimes, students ask questions at night and even on holidays. Online learning emphasizes flexibility; students and lecturers can interact anytime and anywhere [19]. Unless it has been previously stated in the online lectures' rules, discussions and questions are served only during lecture hours.
The data discussion showcases a balance between the material delivery during online and browsing and a balance between online or offline learning methods. Meanwhile, the learning evaluation proves that offline is more desirable and easier for lecturers than that of the online one. It is different from other research results stating that the technology-based instrument for assessing student learning outcomes can reveal student learning outcomes more accurately than the conventional paper-based assessment system (paperbased test) [20]. Therefore, we can conclude that online learning problems are mostly related to the evaluation and assessment, while the media and material delivery methods have various alternatives.

\section{CONCLUSION}

The current study concludes that the shift in the education system due to the Covid-19 pandemic is a precondition for opening lecturers' insights at PPBA to carry out a series of teaching and learning processes using technology. The challenges in teaching Arabic raise the lecturers' creativity and innovation through various technology-based teaching activities. They use several online applications in delivering materials that have never been used before. Technology-based teaching is a new transformation in education, especially in teaching Arabic. Several platforms, such as Google Meet, Google Classroom, WhatsApp, Zoom, and Email, are the alternatives to the conventional classes. This study focuses only on the lecturers' experiences in teaching the Arabic language, so the information presented in this study might not work for all of the courses. Thus, further researches on the other courses are highly suggested. Besides, the next research might examine the students' perceptions who shift their learning processes from the conventional to the virtual one.

\section{REFERENCES}

[1] E. Windhiyana, "DAMPAK COVID-19 TERHADAP KEGIATAN PEMBELAJARAN ONLINE DI PERGURUAN TINGGI KRISTEN DI INDONESIA," Perspekt. Ilmu Pendidik., 2020.
H.
A. Rigianti,
"KENDALA PEMBELAJARAN DARING GURU SEKOLAH DASAR DI BANJARNEGARA," Elem. Sch. J. Pendidik. dan Pembelajaran ke- 
SD-an, 2020.

[3] D. Jamaluddin, T. Ratnasih, H. Gunawan, and E. Paujiah, "Pembelajaran Daring Masa Pandemik Covid-19 Pada Calon Guru : Hambatan, Solusi dan Proyeksi," Karya Tulis Ilm. UIN Sunan Gunung Djjati Bandung, 2020.

[4] R. A. Pangondian, P. I. Santosa, and E. Nugroho, "Faktor - Faktor Yang Mempengaruhi Kesuksesan Pembelajaran Daring Dalam Revolusi Industri 4.0," Semin. Nas. Teknol. Komput. Sains, 2019.

[5] R. Puspitasari, "Hikmah pandemi Covid-19 bagi pendidikan di Indonesia," IAIN Surakarta, 2020. .

[6] I. Mufida, "Mengambil Hikmah dari Munculnya Virus Corona," timesindonesia.co.id, 2020.

[7] T. Tasri, "HIKMAH DI TENGAH WABAH VIRUS CORONA DALAM TINJAUAN HUKUM ISLAM," Qiyas J. Huk. Islam dan Peradil., 2020.

[8] R. M. Putri, A. D. Oktaviani, and A. S. F. Utami, "Hubungan Pembelajaran Jarak Jauh dan Gangguan Somatoform dengan Tingkat Stres Mahasiswa UIN Syarif Hidayatullah Jakarta," Indones. J. Heal. Promot. Behav., 2020.

[9] F. N. Arifa, "Tantangan Pelaksanaan Kebijakan Belajar Dari Rumah Dalam Masa Darurat Covid-19," Info Singkat;Kajian Singk. Terhadap Isu Aktual Dan Strateg., 2020.

[10] F. Firman and S. Rahayu, "Pembelajaran Online di Tengah Pandemi Covid-19," Indones. J. Educ. Sci., 2020.

[11] A. Sadikin and A. Hamidah, "Pembelajaran Daring di Tengah Wabah Covid-19," BIODIK, 2020.
[12] L. D. Herliandry and M. E. S. H. K. Nurhasanah, "Pembelajaran Pada Masa Pandemi Covid-19 Luh,” J. teknlogi Pendidik., 2020.

[13] W. A. F. Dewi, "Dampak COVID-19 terhadap Implementasi Pembelajaran Daring di Sekolah Dasar," EDUKATIF J. ILMU Pendidik., 2020.

[14] R. H. Syah, "Dampak Covid-19 pada Pendidikan di Indonesia: Sekolah, Keterampilan, dan Proses Pembelajaran," SALAM J. Sos. dan Budaya Syar-i, 2020.

[15] M. Siahaan, "Dampak Pandemi Covid-19 Terhadap Dunia Pendidikan," J. Kaji. Ilm., 2020.

[16] S. J. Daniel, "Education and the COVID-19 pandemic," Prospects, 2020.

[17] P. Wahyono, H. Husamah, and A. S. Budi, "Guru profesional di masa pandemi COVID-19: Review implementasi, tantangan, dan solusi pembelajaran daring," J. Pendidik. Profesi Guru, 2020.

[18] L. Handayani, "Keuntungan , Kendala dan Solusi Pembelajaran Online Selama Pandemi Covid-19: Studi Ekploratif di SMPN 3 Bae Kudus Lina Handayani," J. Ind. Eng. Manag. Res., 2020.

[19] Hikmat, E. Hermawan, Aldim, and Irwandi, "Efektivitas Pembalajaran Daring Selama Masa Pandemi Covid-19: Sebuah Survey Online," Digit. Libr. UIN SUnan Gung Djati, Bandung, 2020.

[20] M. A. Hamid, "Pengembangan Instrumen Penilaian Hasil Belajar Siswa Berbasis TIK pada Pembelajaran Dasar Listrik Elektronika," VOLT J. Ilm. Pendidik. Tek. Elektro, 2016. 